\title{
OBITUARY
}

\section{Edward Granville Browne, M.A., M.B., F.B.A., F.R.C.P. 1862-1926.}

A stock of Gloucestershire landowners producing soldiers and business men, with divines and doctors of medicine in former generations, threw up in Edward Granville Browne a genius for Oriental scholarship. Nothing in ancestry or in environment goes any way to explain it, but from the first the boy was not like other boys, and took his own way. Hence most unhappy schooldays at Glenalmond and at Eton, where not only boys but masters objected to his pursuing " bugs" rather than balls. At first destined for engineering, a profession in which his father, Sir Benjamin Browne, had attained distinction, he turned to medicine as a career not too uncongenial and yet of practical value. But already he had found his true path; infected with enthusiasm for the cause of the Turks at the time of their war with Russia in 1877 he set himself to learn their language, and by it was inevitably drawn on to Persian and Arabic. When he came up to Pembroke College, Cambridge, in 1879 , be found it possible in the new atmosphere to work at his Eastern languages side by side with his medicine. As a reward for his second class in the Natural Science Tripos (1882) his father allowed him to take the old Indian Languages Tripos in 1884, and he was of course in the first class and in it alone.

Then followed a period of reading and learning medicine in London relieved by every opportunity of reading and talking with Orientals, particularly Persians, to whom Browne came to be more and more attracted. As a result, though he qualified for the medical profession in 1887 and was preparing to come into residence as house physician at "Barts." early in 1888, suddenly the door opened upon quite another path of life. On 30th May, 1887, he was elected Fellow of his College and was thus enabled to spend that wonderful "year of his life among the Persians". He came to them still young and soattractive and yet steeped in the Qur'an, in their poetry and history, ready to understand their talk and think their thoughts. We can see in his first book how he penetrated the Persian mind and allowed his mind to be penetrated by it. So that for the rest of his life his whole outlook was that of an intelligent of the Near East rather than that of a 
Westerner; or, at any rate, so it appeared to his Western friends. In this year in Persia we may find the sources of the main streams of his interest which flowed on through his life. He never seemed to me really interested in language as language, certainly not in grammar or comparative philology. Language was to him the means to understand and to communicate: life, thought and literature were his ends. Life he first described in his travel-book. A vague tendency towards the occult had shown itself in the London period, it was the London of the first appearance of Theosophy, for the first time English society was feeling drawn to the mysticism of the East. So Browne took an interest in the secte derived from the Assassins, and his earliest papers dealt with those. In Persia the persecuted sect of the Bábís came to his notice, and his first real achievements were along this line. Onlv a man with his attractiveness, his patience and his obvious freedom from any ulterior purpose could have gained the confidence of the Bábís and been allowed by them to come into possession of documents of vital importance for the history of their religion and by comparison for the history of other religions in the obscure stages following the founder's life and death.

On his return from Persia he took the position of University Lecturer in Persian, but pupils were not yet so many as fully to occupy him. So be had time for his next main interest, the history of literature, and produced papers dealing with various sources, especially the Chahar Maqála and other biographies of Persian poets, work preparatory to the greatest of his books, the Literary History, which is esentially one though more than twenty years separated the fourth volume from the first.

In the later nineties the arrangement by which aspirants for Consulships in the Near East came to be sent for special training to Oxford and Cambridge provided Browne with a succession of pupils whom he could lead in the way of knowledge and sympathy. Though not officially head of the school until 1902, when he succeeded Rieu as Professor of Arabic, he was always its mainspring, teaching a great deal himself, and managing both the men and the Oriental instructors. These required careful handling, but afforded him constant practice in talk, which kept his knowlerge fresh and his mind in perpetual rapport with those of Eastern man : in them again he inspired real affection and made their necessary exile tolerable. During this period Browne made many journeys to Paris for study and some further afield to Tunis, Egypt, Cyprus, and to Constantinople. The death 
of his friend, E. J. W. Gibb, brought two new activities : one was the great task of seeing through the Press the last four volumes of a History of Ottoman Poetry, only the first having appeared during the author's lifetime. The other was the administration of the Gibb Trust for publishing Oriental texts : in this the other trustees did their share to help or hinder, but Browne was the main moving spirit, and the splendid row of volumes are as much a memorial to him as to Gibb himself.

The establishment of the Egyptian and Soudan Civil Services brought another set of pupils, and more organization of teachers and taught. Looking back on those years one cannot sufficiently wonder at Browne's marvellous energy. His own production would have been sufficient for a scholar-recluse, but at the same time he was bringing out another man's book, directing a great enterprise for publishing texts, and managing a living machine for instruction in four languages. And all the while he was the most accessible of men, and in his rooms people could find a welcome at every hour of the day or more especially the night. And once there the difficulty was to get away again. It is on record that one caller who came at $6.30 \mathrm{p} . \mathrm{m}$. did not depart till the College doors opened at 6.30 next morning. We came to hear Browne talk, and talk he did on every conceivable subject, and what his talk meant for us Pembroke undergraduates only those who remember it can say : all sorts came up to listen, not only the "highbrows" but the stupid people, and all enjoyed it and were the better for it.

In the early years of the century, Browne's sympathy was engaged by the political decadence of Persia and the threat to its independence from its great neighbours, especially Russia, against which he had a strong prejudice founded originally on disagreeable incidents of his return from Persia in 1888. This appeared to him as one phase of a general aggression by Europe upon the independent powers of Islam, and particularly upon the position of those educated classes in Islamic countries among whom he made his friends. His actual political writings were mostly concerned with Persia, particularly his Persian Revolution of 1905-1909 and his Press and Poetry of Modern Persia: but he made no secret of bis distrust of both British and French policy as well as Russian, and this gave him a leaning towards Germany which had not the same temptations or opportunities. So he sympathized with all oppressed nationalities and liked to trace kindred with the heroes of '98 or declaim a few verses of a Welsh hymn. But if the 
oppressed peoples were Slavonic (except Poles), or Eastern Christians, they somehow failed to touch him; they savoured too much of Russia.

Another great interest was in MSS. ; besides his full catalogue of Persian MSS. in the University Library, he made a hand-list of its Muhammadan MSS. and Supplementary Hand-list of the many MSS. bought under his advice and a List of Muhammadan MSs. in the other Cambridge libraries. His own collection of MSS. was the result of life-long choice, slowly growing from year to year, and in recent times, when means allowed, enriched by great acquisitions from the Schefer collection, from Houtum-Schindler's and 'Abd'ul Majjíd Belshah's. Containing hardly any books of outward comeliness, by which in books or things Browne did not allow himself to be drawn aside, it was almost restricted to texts of the rarer authors, especially those of importance for the history of life and literature. Browne had almost finished a detailed catalogue of his MSS. and strictly charged his executors to publish it. The books themselves will probably find a home in the University Library.

In 1906 Browne married Alice, daughter of F. H. BlackburneDaniell, sometime Fellow of Trinity College, and a well-known authority upon Stuart records. He left two sons, Patrick, now in his first year at Pembroke, and Michael, still at Eton. After his marriage (as he had always forewarned us) College ceased to be the centre of his life, and his rooms became merely classrooms in which was housed most of the work of the University School of Oriental Languages. But at Firwood, his house a mile or so out, he and his wife continued his unbounded hospitality to all kinds of people, and it became a centre to which everyone in need of help would turn at once.

To few could the war bring deeper distress than to Browne with his liking for the Turks, and his strong feeling for the oneness of the learned world. By the end of it his friends began to see him as strangely old, and to wonder what was happening to him. But tired though he felt, he kept on with his work, and finished his great Literary History. He even struck into a new line, a revival of his interest in medicine, in his Fitzpatrick Lectures, before the Royal College of Physicians, upon " $\Lambda$ rabian Medicine". In 1922 he received for his 60 th birthday, besides letters and addresses from all Europe and the Nearer East, a volume of Oriental Studies by scholars of every nation.

A year last November a sudden heart attack brought his active time to an end; he rallied a little, and there was some hope that be might begin his lectures once more, but in June last the sudden death 
of his wife, worn out with caring for him, was a blow from which there was no possibility of recovery; he steadied himself a little to put his affairs in order, and then swiftly sank to die on the 5th of January. He is buried by his wife at his home, Benwell, ontside Newcastle.

In our College Library his works take up more than two feet of shelf room; there is no space here to enumerate all his books, to say nothing of the numberless papers in JRAS. ${ }^{1}$ But the man was more than his books, and not merely among Orientalists, but among all sorts of people, his life will remain a delightful memory, and an abiding inspiration.

\section{Elllis H. Minns.}

1 A complete list of Professor Bronne's works will be found at the end of his Materials for the Study of the Bubi Religion, Cambridge University Press, 1918, and in his Persian Literature in Modern Times (A.D. 1500-1924), Cambridge, 1924.-Ev.] 